\title{
Atrazine Genotoxicity on Human Placental Cells
}

\author{
Ibrahim F. S. ${ }^{1}$, Ali M. M. ${ }^{1}$, Issak M. ${ }^{1}$, Ewaiss M. ${ }^{2}$ \\ ${ }^{1}$ Forensic medicine and clinical toxicology department, faculty of medicine, Cairo University, Cairo, Egypt \\ ${ }^{2}$ Medical biochemistry and molecular biology department, faculty of medicine, Benisueif university, Benisueif, Egypt
}

\section{Email address:}

samahibraheem@yahoo.com (Ibrahim F. S.), mona_mohamed_aly@yahoo.com (Ali M. M.), missak1978@hotmail.com(Issak M.), manal_ewaiss@yahoo.com (Ewaiss M.)

\section{To cite this article:}

Ibrahim F. S., Ali M. M., Issak M., Ewaiss M.. Atrazine Genotoxicity on Human Placental Cells. American Journal of Clinical and Experimental Medicine. Vol. 3, No. 4, 2015, pp. 194-199. doi: 10.11648/j.ajcem.20150304.21

\begin{abstract}
Atrazine is one of the most commonly used herbicides. After exposure to Atrazine during pregnancy, it can be found in placental tissue. We investigated the toxic effects of different Atrazine concentrations on human cytotrophoblasts. These cells were isolated from fresh placenta and were exposed to Atrazine for 24 hours. Our results showed that very low doses of Atrazine induced apoptotic placental cell death. It decreased the relative survival of human cytotrophoblastsup to 50\% of control. It significantly decreased P53 and TNF- alpha genes expression while Bcl2 gene expression was increased insignificantly. Our findings suggested that exposure of placental cells to Atrazine even in low doses causes harmful effects, leading to adverse pregnancy outcomes such as preeclampsia, intrauterine growth restriction, prematurity and pregnancy loss.
\end{abstract}

Keywords: Atrazine, Placenta cytotrophoblasts, mRNA, Bc12, P53, TNF- $\alpha$

\section{Introduction}

Atrazine, a herbicide used to control weeds in cultivation $\left(\mathrm{Oh}\right.$ et $\left.\mathrm{al}^{1}\right)$, is classified as moderately toxic herbicide by US environmental protection agency (USEPA ${ }^{2}$ ).In Egypt; its utilization was increased since 2000 (Mona et al., ${ }^{3}$ ).

After oral ingestion of atrazine, it passes through the lining of intestine then enters the bloodstream and is distributed to many parts of body especially placenta (Rohr and Crumrine $^{3}$ ).Apoptosis plays a critical role in different stages of placental development, that is essential for fetal growth as it delivers nutrients and oxygen to the fetus. Placental apoptosis occurs through immune-mediated extracellular ligands and receptors such as TNF- $\alpha$ and its receptor type1.As well as endogenous death signal molecules such as the P53 and Bcl-2 family genes (Allaire et $\mathrm{al}^{4}$ ).TNF- $\alpha$ is produced in the villous placenta throughout pregnancy and is implicated in regulating placental apoptosis5(Levy and Nelson ${ }^{5}$ ). The p53 protein is a tumor suppressor gene product, whose wild-type is able to negatively regulate cell proliferation by arresting the growth in G1and maintain genetic integrity (Cantemir et $\mathrm{al}^{6}$ ).Enhanced cell apoptosis is associated with increasing the expression of the TNF- $\alpha$ gene and pro-apoptotic proteins p53along with decreasing the expression of the anti-apoptotic protein $\mathrm{Bcl}-2$ (Kharfi et $\mathrm{al}^{7}$ ).Disruption of the reproductive system by Atrazine begins when disruption of cell signaling occurs. However, the exact mechanism by which atrazine exerts its toxic effects in human placenta aren't clear (Oh et al ${ }^{1}$; Pathak \& Dikshit $\left.{ }^{8}\right)$.

\section{Aim of the Work}

Enhancing apoptosis in human trophoblasts that exposed to different low doses of Atrazine were evaluated by detecting the expression levels of $\mathrm{P} 53, \mathrm{Bcl} 2, \mathrm{TNF}-\alpha$ genes and measuring human cytotrophoblast relative survival.

\section{Materials and Methods}

Dulbecco's modified Eagle medium (DMEM), fetal calf serum, and 3-(4, 5-dimethylthiazol-2-yl)- 2, 5diphenyltetrazoliunbromide (MTT) were purchased from GIBCO BRL (Grand Island, NY, USA). Trypsin 2.5\%, penicillin, streptomycin, atrazin and all other chemicals employed in this study were of analytical grade and were purchased from Sigma Chemical Co. (St. Louis, USA).

\subsection{Cell Culture and Cell Proliferation Assay}

Atrazine was dissolved in complete DMEM, the $\mathrm{pH}$ value was adjusted to 7.2 and sterilized through a $0.2 \mu \mathrm{m}$ filter to the desired working solutions. Human placental cell line was cultured in DMEM medium supplemented with 5\% fetal 
bovine serum (FBS), $100 \mathrm{mg} / \mathrm{mL}$ streptomycin and 100 units/mL penicillin at $37{ }^{\circ} \mathrm{C}$ in a humidified incubator in an atmosphere of $5 \% \mathrm{CO}_{2}$. Cells were seeded in 96-well plates $\left(10^{3}-10^{4}\right.$ cells/well) for 24 hours incubation, cell viability was evaluated using MTT assay as described by Cui et al $^{9}$.In brief, cells were treated with atrazine at a various concentration $0,1,10,30 \mu \mathrm{M} / \mathrm{ml}$ for 24 hours and untreated cells served as a control. Prior to determination, $10 \mu \mathrm{L}$ MTT $(2.5 \mathrm{~g} / \mathrm{L})$ was added to each well. After 4 hours incubation, the culture media were discarded followed by addition of 100 $\mu \mathrm{L}$ of detergent reagent to each well and vibration for $10 \mathrm{~min}$. The absorbance (A) in the experimental wells was measured at $570 \mathrm{~nm}$ with a microplate reader (ELISA reader). The absorbance in the experimental wells to that of the control wells. The cytotoxicity percentage of viable cells was calculated as follows: (A of experimental group/A of control group) $\times 100 \%$.

\subsection{Total RNA Isolation}

Cells were detached by trypsin (2.5\%) and total RNA was isolated with RNA assay Mini Kit (Qiagen) and further analyzed for quantity and quality with Beckman dual spectrophotometer (USA). The RNA integrity and the GAPDH-RNA (housekeeping gene) ratio were used as the quality control.

\subsection{Real Time PCR (qRT-PCR) for Quantitative Expression of P53, Bcl2 and TNF-Alpha}

The mRNA expression level was quantified by qRT-PCR (Real time PCR). $1000 \mathrm{ng}$ of the total RNA from each sample were used for cDNA synthesis by reverse transcription using High capacity cDNA Reverse Transcriptase kit (Applied Biosystem, USA). The cDNA was subsequently amplified with the Syber Green I PCR Master Kit (Fermentas) in a 48- well plate using the Step One instrument (Applied Biosystem, USA) as follows: 10 minutes at $95^{\circ} \mathrm{C}$ for enzyme activation followed by 40 cycles of 15 seconds at $95^{\circ} \mathrm{C}, 20$ seconds at $55^{\circ} \mathrm{C}$ and 30 second at $72^{\circ} \mathrm{C}$ for the amplification step. Changes in the expression of each target gene were measured relative to the mean critical threshold (CT) values of GAPDH housekeeping gene by the $\mathrm{Ct}$ method. We used $1 \mu \mathrm{M}$ of both primers specific for each target gene. Primers sequence specific for each gene demonstrated in (table 1).

\subsection{Statistical Methods}

Data were statistically described in terms of mean \pm standard deviation. Comparison of quantitative variables was done using Mann- Whitney test. Correlation was done to test for linear relations between quantitative variables by Spearman correlation coefficient. A probability value ( $P$ value) less than 0.05 was considered statistically significant. All statistical calculations were done using SPSS (Statistical Package for the Social Science; SPSS Inc., Chicago, IL, USA) version $21\left(\right.$ Chan $\left.^{10}\right)$.

Table (1). Primers sequence specific for P53, Bcl2 and GADPH genes.

\begin{tabular}{ll}
\hline Target gene & Primer sequence: $\mathbf{5}-\mathbf{3}$ \\
\hline \multirow{2}{*}{ P53 } & Forward: AGAGTCTATAGGCCCACCCC \\
& Reverse: GCTCGACGCTAGGATCTGAC \\
Bc12 & Forward: TTTACGAGAAGCTTGGAGAG \\
& Reverse: TGTGCAGATATCAGAGTGGA \\
GAPDH & Forward: CCTCTACTGGCGCTGCCAAGGCT \\
& Reverse: GTCCACCACTGACACGTTGG \\
\hline
\end{tabular}

\section{Results}

Our results showed that small doses of Atrazine (1, 10 and $30 \mu \mathrm{M} / \mathrm{ml}$ ) were cytotoxic for human cytotrophoblasts, as they induced apoptotic and necrotic cell death (Table 2).

Table (2). Apoptotic effects of different Atrazine's concentrations in human cytotrophoblasts after 24 hours.

\begin{tabular}{llll}
\hline Cell line treated with Atrazin Apoptotic parameters & $\mathbf{0 \mu M} / \mathbf{m l}$ & $\mathbf{1} \boldsymbol{\mu M} / \mathbf{m l}$ & $\mathbf{3 0 \mu M} / \mathbf{m l}$ \\
\hline $\begin{array}{l}\text { Extrinsic pathway parameter } \\
\text { TNF-alpha }\end{array}$ & $1.3 \pm .89$ & $.69 \pm .14$ & $.25 \pm .11$ \\
Intrinsic pathway parameters & & & \\
p53 & $1.42 \pm .31$ & $.16 \pm .04$ & $.15 \pm .06$ \\
Bcl2 & $1.35 \pm .21$ & $1.65 \pm .65$ & $.13 \pm .14$ \\
Cell viability & & $.04 \pm .02$ & $.78 \pm .26$ \\
MTT assay & $.58 \pm .10$ & $.28 \pm .08$ & $.15 \pm .05$ \\
Relative survival (\%) & 100 & $49.9 \pm 17.5$ & $.14 \pm .15$ \\
\hline
\end{tabular}

Cytotoxicity of Atrazine was determined through relative survival and MTT assay of human cytotrophoblats. The Atrazine concentrations 1,10 and $30 \mu \mathrm{M} / \mathrm{ml}$ induced nearly 50,75 and $77 \%$ growth inhibition in relation to the control and significantly altered the growth of the cells (table 2 and figure1). Moreover, Relative survival of human cytotrophoblasts showed significant negative correlation with Atrazine's concentrations (figure 2).

We demonstrated that Atrazine was able to affect intrinsic apoptotic pathway through affecting p53 and $\mathrm{Bcl} 2$ genes expression. P53gene expression decreased significantly $(0.16 \pm .04,0.13 \pm .14$ and $0.04 \pm .02)$ with increasing Atrazine dose (table 2 and figure 3 ). Moreover, it showed a significant positive correlation with $\mathrm{Bcl} 2$ genes (figure 4).

Although, Bcl2 was not significantly enhanced $(1.65 \pm 0.65)$ at Atrazine concentration $1 \mu \mathrm{M} / \mathrm{ml}$, it significantly decreased $(0.78 \pm .26$ and $0.44 \pm .22)$ with Atrazine concentrations ranged between 10 and $30 \mu \mathrm{M} / \mathrm{ml}$ (table 2 and figure 5).

Atrazine was also able to affect the extrinsic apoptotic pathway through modulation of TNF- $\alpha$ gene expression. 
Indeed, we revealed that mRNA levels of TNF- $\alpha$ reduced significantly $(0.69 \pm .14,0.25 \pm .11$ and $0.15 \pm .06)$ by Atrazine doses (1, 10 and $30 \mu \mathrm{M} / \mathrm{ml}$ respectively) (table 2 and figure 6).
TNF- alpha gene showed a significant positive correlation with p53 and $\mathrm{Bcl} 2$ genes expression (figure 7).

\section{MTT}

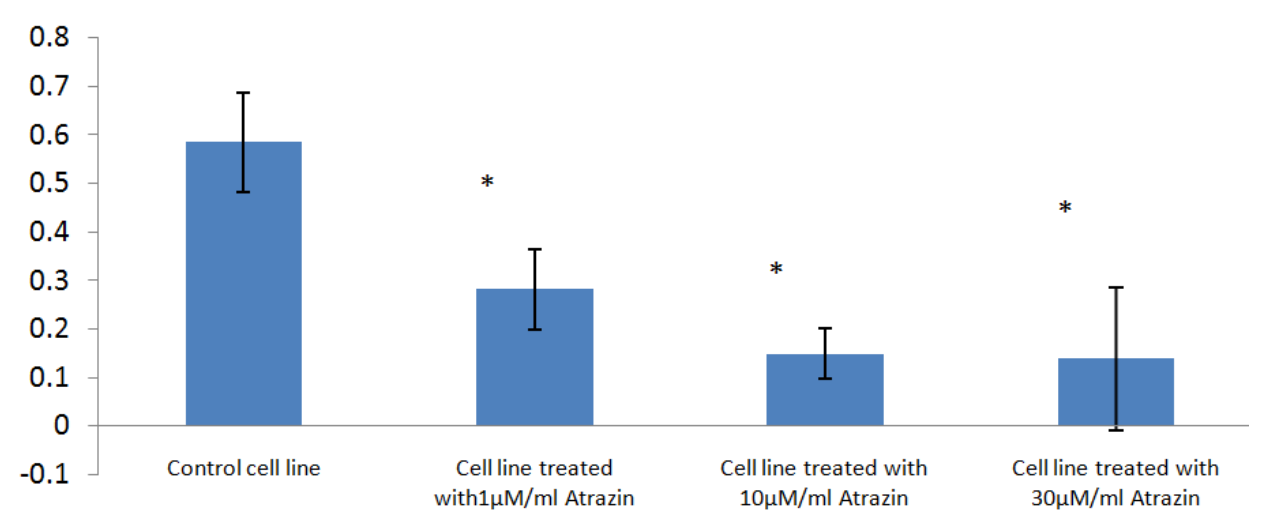

* significant difference at $\mathrm{P}<0.05$.

Figure (1). MTT- assay in human cytotrophoblasts exposed to different Atrazine's concentrations. Statistical analysis.

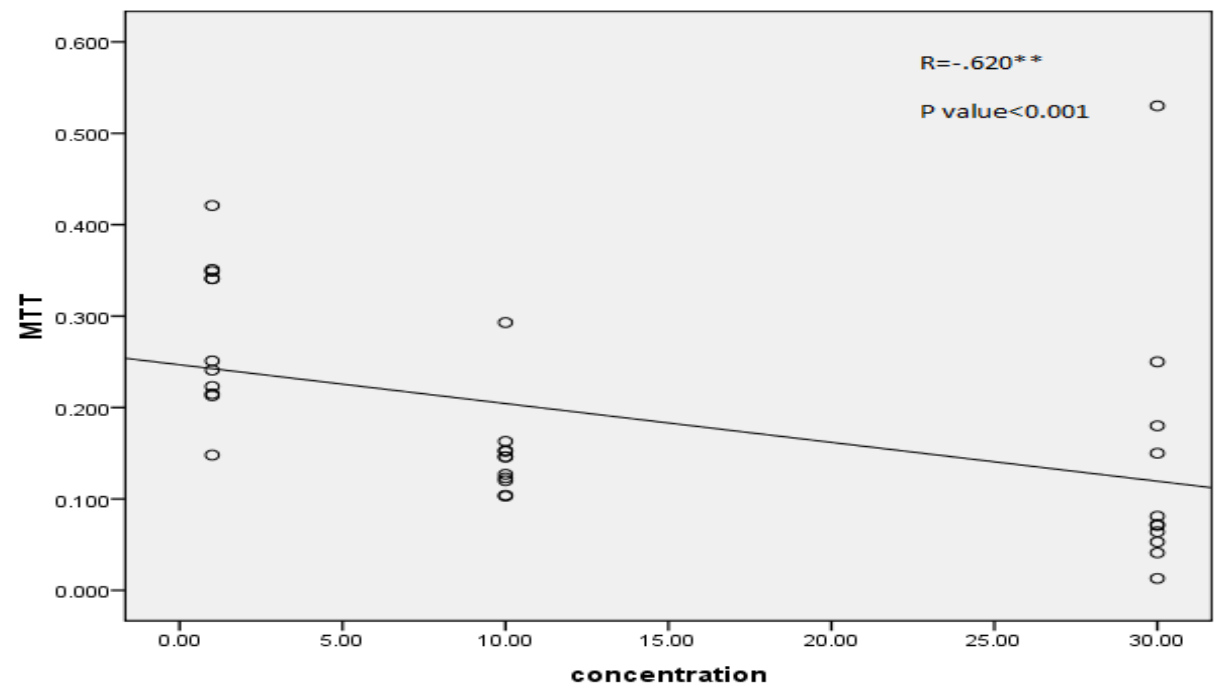

Figure (2). correlations between MTT assay and different Atrazine's concentrations in human cytotrophoblasts.

p53

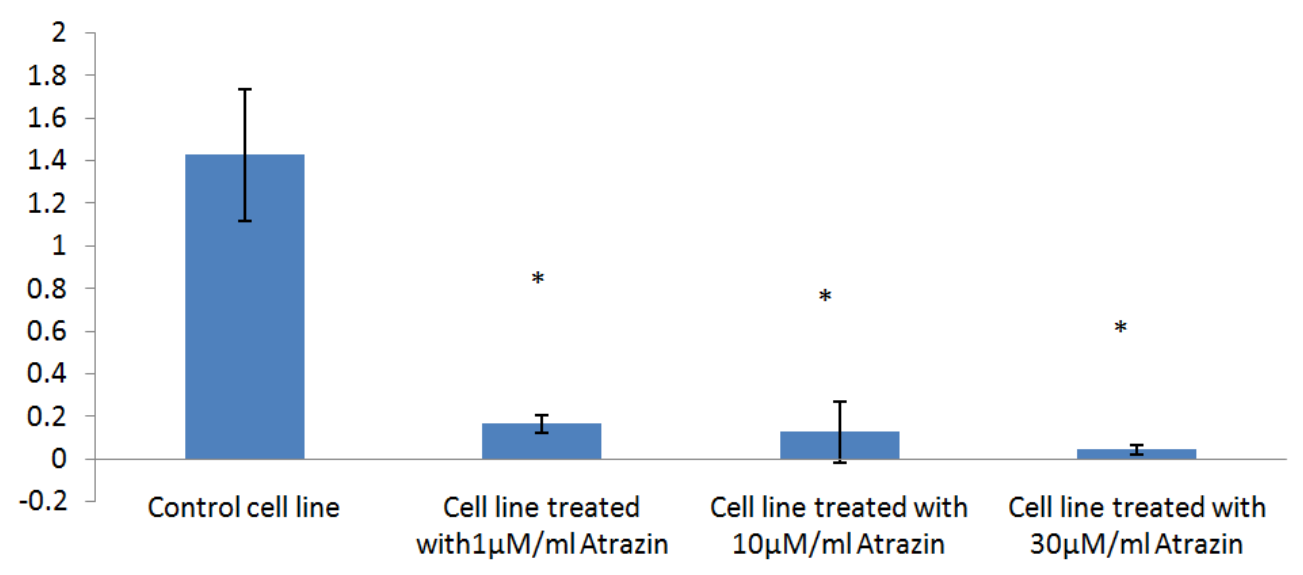

* significant difference at $\mathrm{P}<0.05$

Figure (3). p53 gene expression in human cytotrophoblasts exposed to different Atrazine's concentrations. Statistical analysis. 


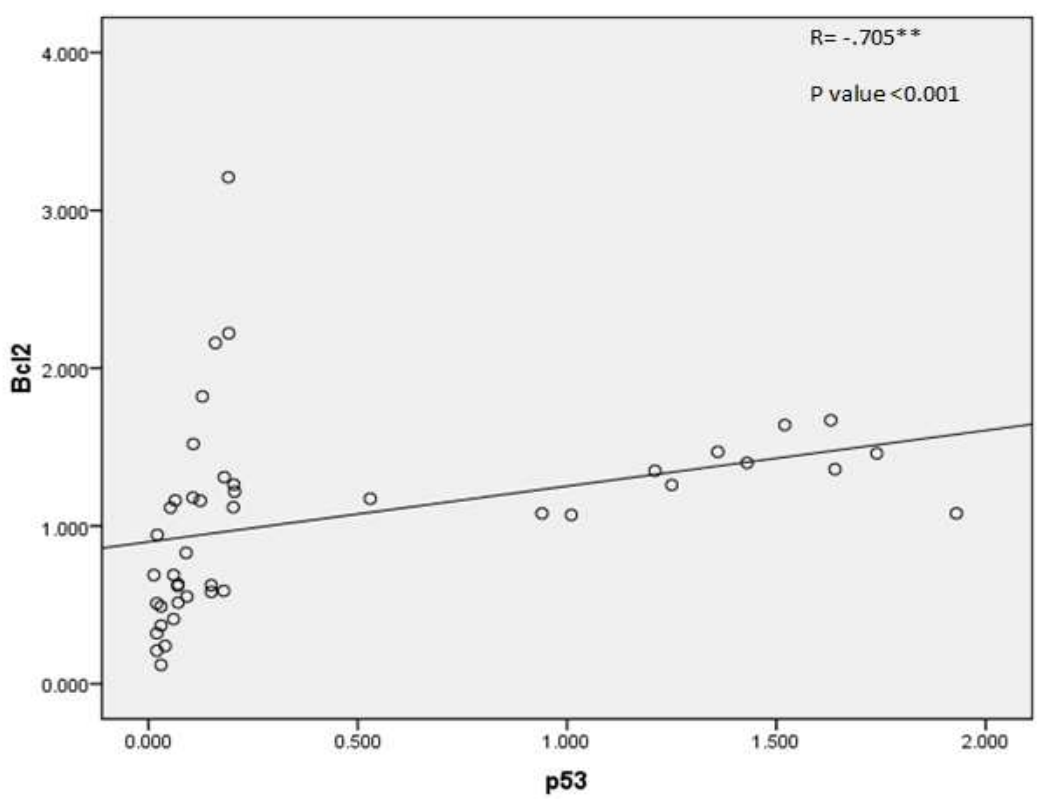

Figure (4). correlation between Bcl2 and p53 gene in Atrazine exposed human cytotrophoblasts.

\section{$\mathrm{Bcl} 2$}

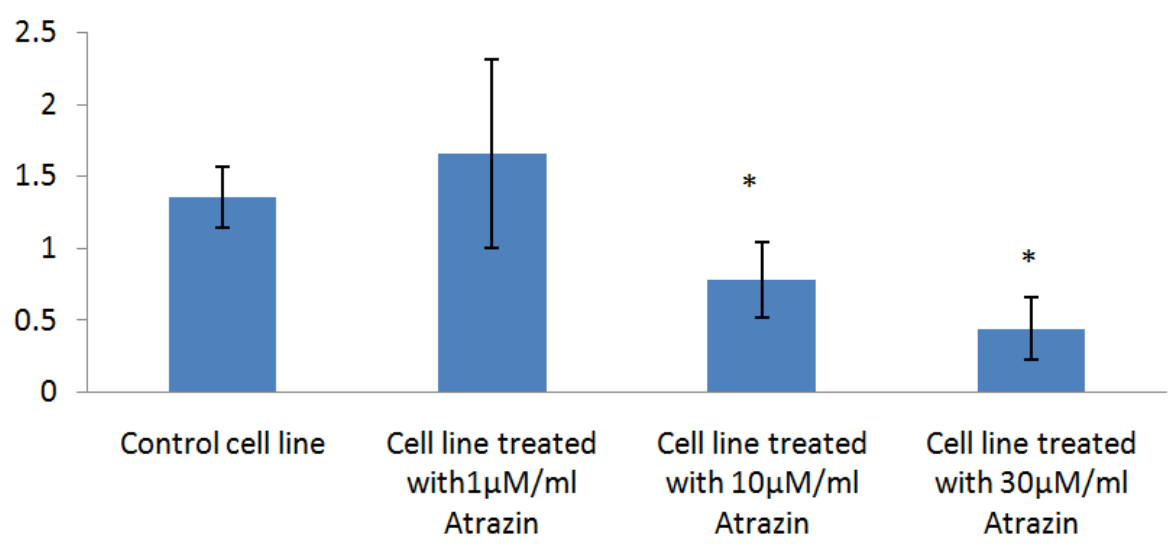

* significant difference at $\mathrm{P}<0.05$.

Figure (5). Bcl2 gene expression in human cytotrophoblasts exposed to different Atrazine's concentrations. Statistical analysis.

\section{TNF-alpha}

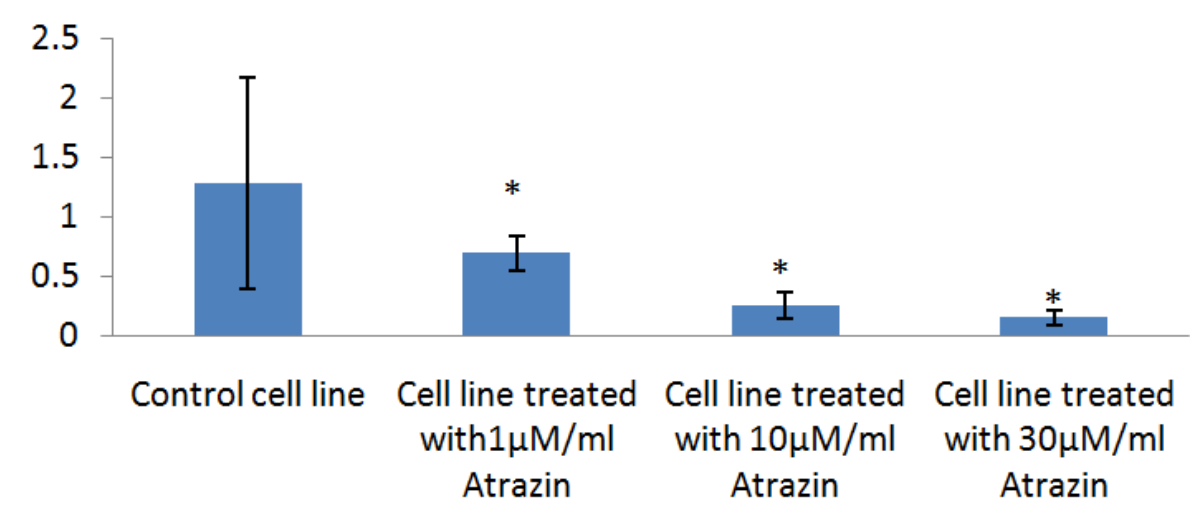

* significant difference at $\mathrm{P}<0.05$

Figure (6). TNF-alpha gene expression in human cytotrophoblasts exposed to different Atrazine's concentrations. Statistical analysis. 

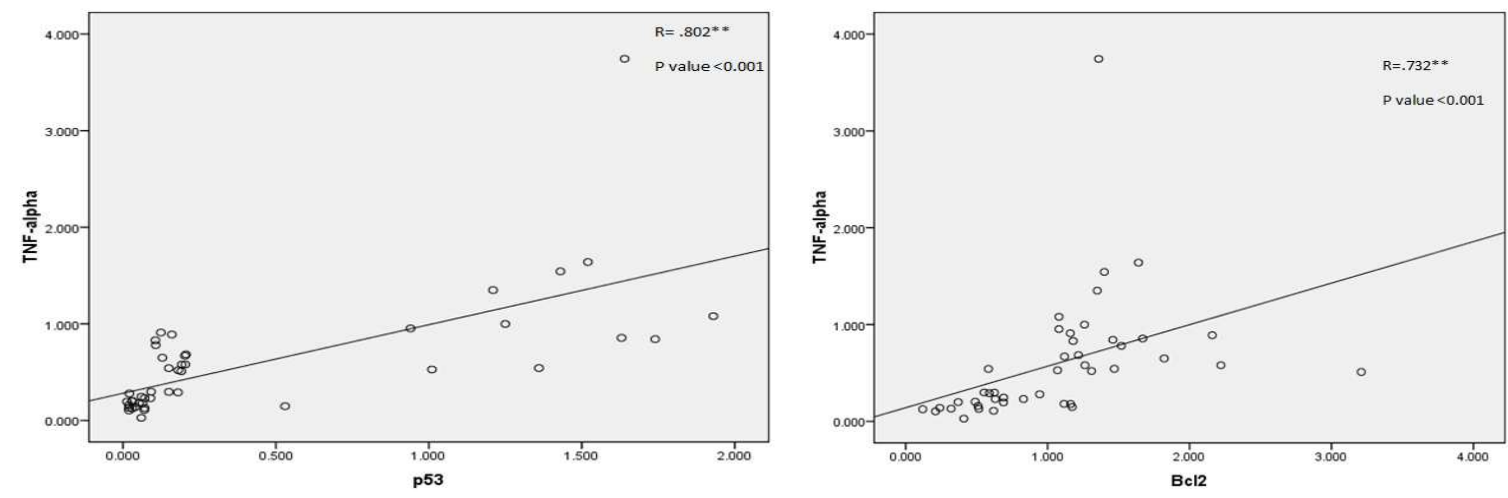

Figure (7). correlation between p53, Bcl2 and TNF- alpha gene in Atrazine exposed human cytotrophoblasts.

\section{Discussion}

In this study, we showed a dose-dependent enhanced apoptotic cell death of human cytotrophoblasts after exposure to atrazine in different doses.

Regarding atrazine's effects on cytotrophoblat relative survival, we were not in the same line with Jung Kim and Chun Ryu ${ }^{11}$ who investigated the effect of different doses of atrazine on Rat 2 lacI transgenic fibroblasts, found $20 \%$ cell growth inhibition was resulted from using $261.7 \mu \mathrm{g} / \mathrm{mL}$ of atrazine that was higher than ours. This may be due different sample type.

Our results were similar to those of Nwani et $\mathrm{al}^{12}$ whoevaluated the genotoxic and mutagenic effects of the Rasayanzine herbicide, whose active ingredient is atrazine. They stated that all tested concentrations up to $8.48 \mathrm{mg} / \mathrm{L}$ showed significant genotoxic and mutagenic effects and arranged a dose response curve for their results.

Atrazine induced apoptosis through affecting the intrinsic pathway more than extrinsic one. Our finding coincided with the study results carried by Zhang et $\mathrm{al}^{13}$ in which mice administered atrazine exhibited a significant apoptotic activity in a dose dependent manner through increasing the expression of Fas, FasL and caspase-3.

Concerning TNF- $\alpha$, Benachouret $\mathrm{al}^{14}$ stated that TNF is produced in the villous human placenta throughout pregnancy and induced placental apoptosis. If TNF-ais modulated by low doses of Atrazine, the placenta will be harmfully affected.

Regarding $\mathrm{p} 53$,Deng et $\mathrm{al}^{15}$ discovered that the direct apoptogenic role of $\mathrm{p} 53$ is induced through induction of $\mathrm{p} 53$ $\mathrm{Bcl} 2$ binding that causes DNA damage.

Elevated apoptotic factors, as shown in our study especially $\mathrm{p} 53$, cause failure or deficiency in trophoblast proliferation or differentiation, this will compromise placental development in pregnancies and complicated by IUGR and fetal death (Benachour ${ }^{14}$ ).

\section{References}

[1] Oh SM, Shim SH, Chung KH. Antiestrogenic action of atrazine and its major metabolites.Journal of Health Science. 2003, 49(1) 65-71.
[2] USEPA. National Air Quality and Emissions Trends Report 2003.Special Studies Edition, 2003.Available:http://epa.gov/air/airtrends/aqtrnd03/pdfs/toc.

[3] Mona M H,Reda MG, Ibrahim BH, NahlaEO ,Wesam MS .Evaluation of cytotoxic effects of atrazine and glyphosate herbicides on Biomphalariaglabrata snails. The Journal of Basic \& Applied Zoology. 2013, 66 (2): 68-75.

[4] Rohr JR, Crumrine PW. Effects of an herbicide and an insecticide on pond community structure and process.Ecological Applications 2005, 15(4), 1135-1147.

[5] Allaire $\mathrm{AD}$, Ballenger KA, Wells SR, McMahon MJ, LesseyBA.Placental apoptosis in preeclampsia. Obstet Gynecol. 2000; 96(2):271-276.

[6] Levy R, Nelson DM. To be, or not to be, that is the question. Apoptosis in human trophoblast. Placenta 2000, 21(1);1-13.

[7] Cantemir C, Cozmei C, Scutaru B, Nicoara S, Carasevici E. p53 Protein expression in peripheral lymphocytes from atrazine chronically intoxicated rats. Toxicol Letters. 1997, 93(2-3); $87-94$.

[8] Kharfi A, Bureau M, GiguèreY,MoutquinJM, Forest JC. Dissociation between increased apoptosis and expression of the tumornecrosisfactoralpha system in term placental villi with preeclampsia.ClinBiochem. 2006 ;39(6):646-51.

[9] PathakRK ,Dikshit AK. Atrazine and Human Health.International Journal of Ecosystem.2011, 1(1): 14-23.

[10] Cui, F.J., Li, Y., Xu, Y.Y., Liu, Z.Q., Huang, D.M., Zhang, Z.C et al. Induction of apoptosis in SGC-7901 cells by polysaccharide peptide GFPS1b from the cultured mycelia of GrifolafrondosaGF9801.Toxicol In Vitro. 2007;21(3):417-427.

[11] Chan, Y.H. Biostatistics102: Quantitative Data - Parametric \& Non parametric Tests. Singapore Med. J.2003; 44(8): 391-396.

[12] Jung Kim Y, Chun Ryu J. Genotoxicity Assessment of Atrazine in the Big Blue ${ }^{\circledR}$ Rat2lacI Transgenic Cell Line. Toxicol. Environ. Health. Sci. 2012, 4(3), 161-166.

[13] Nwani CD, Nagpure NS, Kumar R, Kushwaha B, Kumar P, Lakra WS. Mutagenic and genotoxic assessment of atrazinebased herbicide to freshwater fish Channapuntatus(Bloch) using micronucleus test and single cell gel electrophoresis. Environ ToxicolPharmacol. 2011;31(2):314-22.

[14] Zhang X, Wang M, Gao S, Ren R, Zheng J , Zhang Y. Atrazine-induced apoptosis of splenocytes in BALB/C mice. BMC Medicine. 2011, 9:117. 
[15] Benachour N,Aris A.Toxic effects of low doses of Bisphenolon human placental cells. ToxicolApplPharmacol. 2009; 241(3):322-8
[16] Deng X, Gao F, Flagg T, Anderson J, Stratford S. Bcl2's Flexible Loop Domain Regulates p53 Binding and Survival. Mol Cell Biol. 2006; 26(12):4421-34 